\title{
Peers rally in support of accused scientist
}

\section{Erika Check, Washington}

Two leading US scientific organizations have lambasted the government's treatment of an infectious-disease expert who faces multiple criminal charges after mishandling plague samples.

In a letter to Attorney General John Ashcroft, Bruce Alberts, the president of the National Academy of Sciences, and Harvey Fineberg, who heads the Institute of Medicine, said that the prosecution of the researcher, Thomas Butler of Texas Tech University in Lubbock, was endangering US bioterrorism research.

Butler was arrested in January for giving incorrect information about samples of the plague bacterium Yersinia pestis he had transported to Texas from Tanzania. Initially, Butler, who was chief of infectious diseases at Texas Tech, had reported that the samples were lost, and then confessed that he had destroyed them. The US Department of Justice charged Butler with illegally transporting the vials, lying to federal agents, and filing a false 2001 tax return.

If convicted on all current counts, Butler could pay as much as $\$ 3.6$ million in fines and go to prison for 74 years, according to the National Academies' Committee on Human Rights. Additional charges are expected to be filed before his trial, set for 6 October in Lubbock.

In their letter to Ashcroft, Alberts and Fineberg wrote: "We are particularly concerned about the impact that Dr Butler's case may have on other scientists who may be discouraged from embarking upon or continuing crucial bioterrorism-related scientific research - thereby adversely affecting the nation's ability to fully utilize such research capabilities in preparing

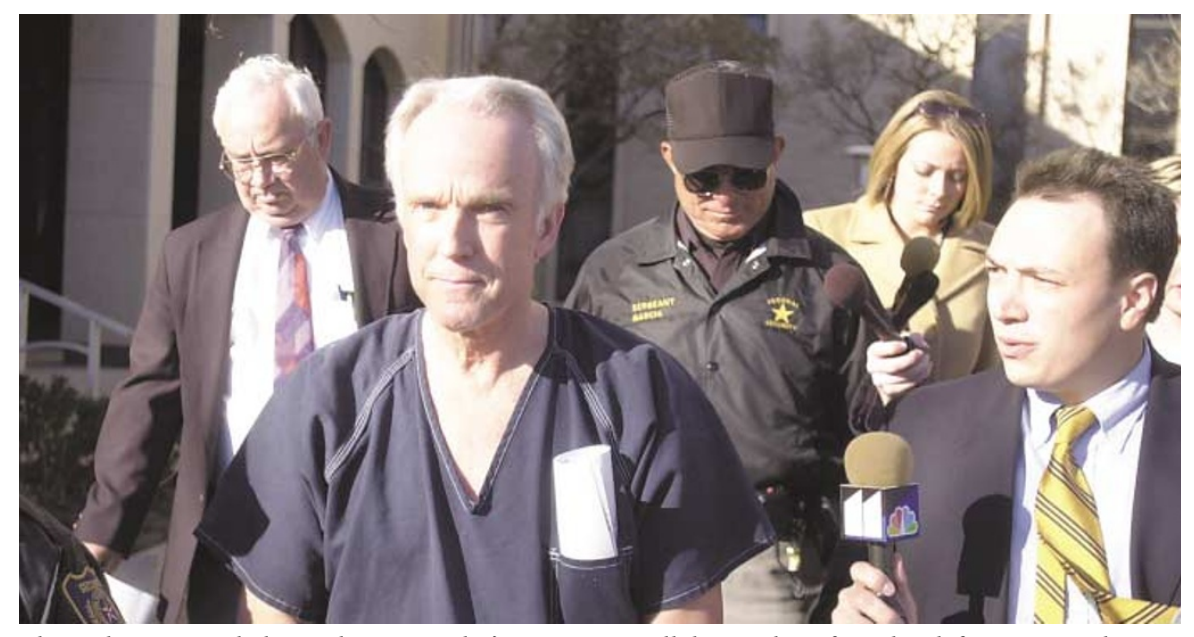

Plagued: scientists believe Thomas Butler's treatment will deter others from biodefence research.

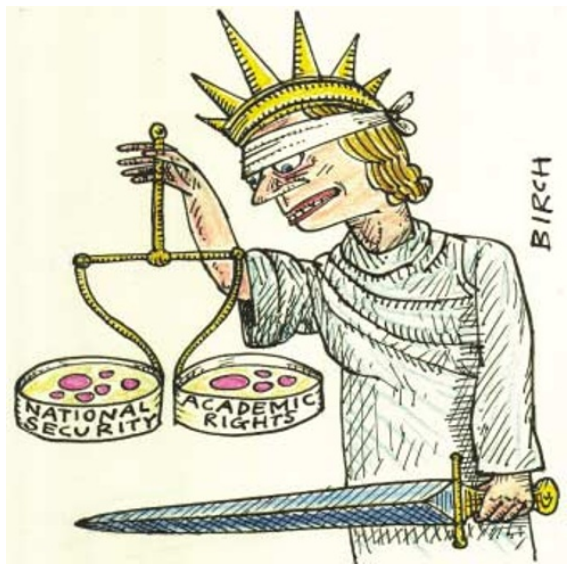

defenses against possible bioterrorist attacks."

On 28 August, the human-rights committee wrote to its membership - 1,700 senior scientists, engineers and doctors 21 asking them to support Butler by writing to Texas Tech, the US government and Butler. It also requested donations for Butler's defence space policy that was nearly complete at the time of the Columbia accident. That project was shelved but now is being revived with the Gehman report in mind, for completion early next year, just in time to feed into the Bush administration's 2005 budget request.

Meanwhile, NASA may report as early as this week on its latest plan for returning the shuttle to flight. The earlier target launch date of next spring now looks unlikely, as does the pre-accident plan to complete the US segments of the International Space Station within a year of the next shuttle launch. The Gehman panel's report cited pressure to finish the station on schedule as a contributing cause of the accident.
The current US federal deficit and the mounting costs of the war in Iraq make any grand expansion of NASA's budget unlikely, but some commentators say that political factors may be coming together for a renewed US commitment to human space exploration. Howard McCurdy, a spacepolicy expert at the American University in Washington, says that President Bush may be under pressure to make such a commitment. "Historically," he says, "no major political figure with the authority to make the decision has ever wanted to put his or her fingerprints on a decision to start closing down the manned-spaceflight programme."
— so far, he has paid his lawyers $\$ 400,000$, the alert says.

Nobel laureate Torsten Wiesel, who chairs the human-rights committee, says that the only other case in which the committee has taken similar steps on behalf of a US scientist was the prosecution of Wen Ho Lee, the Los Alamos National Laboratory researcher who was accused of stealing US nuclear secrets in 1999.

But the committee was compelled to act in Butler's case because of what seemed to be a severity of punishment out of proportion to his crime, Wiesel says. "Rather drastic steps have been taken against him, and we want to ensure that he is being dealt with properly by the justice department and the university," he explains.

Texas Tech has prevented Butler from returning to its campus at Lubbock and is planning to testify against him at his trial; Butler, meanwhile, is becoming depressed, Wiesel says.

Wiesel also warns of the case's broader significance. He says that several scientists have told the National Academies that the Butler prosecution is scaring US researchers away from biodefence work, because they perceive Butler to be a scientist who has merely been caught unaware by the rules.

"It's a serious mistake because he is one of the internationally recognized experts in plague," Wiesel says. "This has certainly sensitized the community, which is not helpful if you really are concerned about bioterrorism."

Steven Block, a biophysicist at Stanford University, adds: "The Department of Justice should go after individuals who pose serious, credible threats to our national security, not hapless biomedical scientists who are simply pursuing their research, but failing to fill out the mounds of paperwork mandated by the bureaucracy." 